\title{
Investment risk in the energy sector on the example of a biogas power plant
}

Abstract: The aim of the article is to present the issue of risk and related management methods, with a particular emphasis on the conditions of investment in energy infrastructure. The work consists of two main parts; the first one is the theoretical analysis of the issue, while the second discusses the application of analysis methods on the example of the investment in an agricultural biogas plant.

The article presents the definitions related to the investment risk and its management, with a particular emphasis on the distinction between the risk and uncertainty. In addition, the main risk groups of the energy sector were subjected to an analysis. Then, the basic systematics and the division into particular risk groups were presented and the impact of the diversification of investments in the portfolio on the general level of risk was determined. The sources of uncertainty were discussed with particular attention to the categories of energy investments. The next part of the article presents risk mitigation methods that are part of the integrated risk management process and describes the basic methods supporting the quantification of the risk level and its effects - including the Monte Carlo (MC), Value at risk (VaR), and other methods. Finally, the paper presents the possible application of the methods presented in the theoretical part. The investment in agricultural biogas plant, due to the predictable operation accompanied by an extremely complicated and long-term investment process, was the subject of the analysis. An example of "large drawing analysis" was presented, followed by a Monte Carlo simulation and a VaR value

\footnotetext{
${ }^{1}$ Warsaw University of Technology, Electrical Power Engineering Institute, Division of Power Plants and Power Engineering Economics, Warszawa, e-mail: kalinskj@ee.pw.edu.pl, Jozef.Paska@ien.pw.edu.pl, Karol.Pawlak@ien. pw.edu.pl, Pawel.Terlikowski@ien.pw.edu.pl, dawid.urbanek@op.pl
} 
determination. The presented study allows for determining the risk in the case of deviation of financial flows from the assumed values in particular periods and helps in determining the effects of such deviations. The conducted analysis indicates a low investment risk and suggests the ease of similar calculations for other investments.

KEYWORDS: Investment risk, risk management, uncertainty, Monte Carlo, Value at risk, biogas plant

\section{Introduction}

The issue of investment risk in the energy sector is extremely important due to the dynamics of the energy sector development, which is characterized by high capital intensity, while the correct development of the sector has a huge impact on the entire economy. For this reason, it is necessary to properly manage the risk at every stage of the investment process. Risk analysis a complex process, but its correct implementation brings tangible benefits for both the investor and end-users.

The aim of the article is a cross-sectional analysis of the problem and related issues. The currently available literature on the subject is extremely rich, but the purpose of this publication is to systematize definitions and concepts in the field of broadly understood risk issues, as well as to show the practical application of risk management and quantification methods. The first part of the work describes the current approach to the issue of investment risk in the energy sector, sources of its occurrence, quantitative description, and management in detail. The author's risk analysis on the example of investment in a biogas plant presents the possibilities of using analytical methods to support investment decisions. This analysis can be extended depending on the complexity of the project and its type.

The investment risk is a complex issue, while the indication of its sources and its comprehensive management are difficult tasks. However, in order to reduce the risk, it must be analyzed at each stage of the investment process. Proper risk management is also of great importance in basic project management methods, including, among others, PRINCE2 (Hinde 2012) and PMBOK (Conchúir 2011). Based on the observation of the above methodologies, experience of the project managers, and the literature on the subject, a special emphasis on the identification of the main risk groups is clearly visible. This is the starting point for the use of subsequent points from a wide list of elements of the risk management process. 


\section{The concept of risk}

The starting point for the properly conducted analysis is to precisely define the terms. It turns out that the concept of risk, though commonly intuitively understood, is difficult to be clearly defined. The Polish Language Dictionary defines the risk as (Risk 2018):

1. The possibility that something goes wrong; also: project whose outcome is uncertain.

2. The willingness to take such a risk.

3. The liability for damage regardless of fault, unless the contract or legal provision oblige another person to compensate for the damage.

A related concept, distinguished by many authors dealing with the issue of investment risk, is the concept of uncertainty. The difference between these terms is precisely presented, among others, by (Marcinek 2010) and (Ostrowska 2002). In both publications, the authors defined uncertainty as a state of doubt about the future, without the possibility of quantifying it, while the risk was defined as a measurable quantity. In further consideration these concepts will be used in this sense.

\section{Risk sources}

In the literature (Ostrowska 2002), the causes of risk are divided into the following groups, based on the source of its occurrence:

$\downarrow$ Microeconomic factors - resulting from hazards characteristic of a given branch of the economy or more narrow categories such as the specific character of a given company;

$\downarrow$ Mezoeconomic factors - sectoral factors, in this case, issues related to the energy industry;

$\checkmark$ Macroeconomic factors - the widest concept, affected by world trends or politics.

However, these points are closely related and cannot be analyzed separately.

Another division is based on determining the specific and systematic risks (Fig. 1). The former is related to the specific nature of the investment or a branch. The latter is understood as the ever-present risk, which you can't get rid of and its reduction is only possible to a limited extent. This risk originates mainly from macroeconomic risk groups (Ostrowska 2002). 


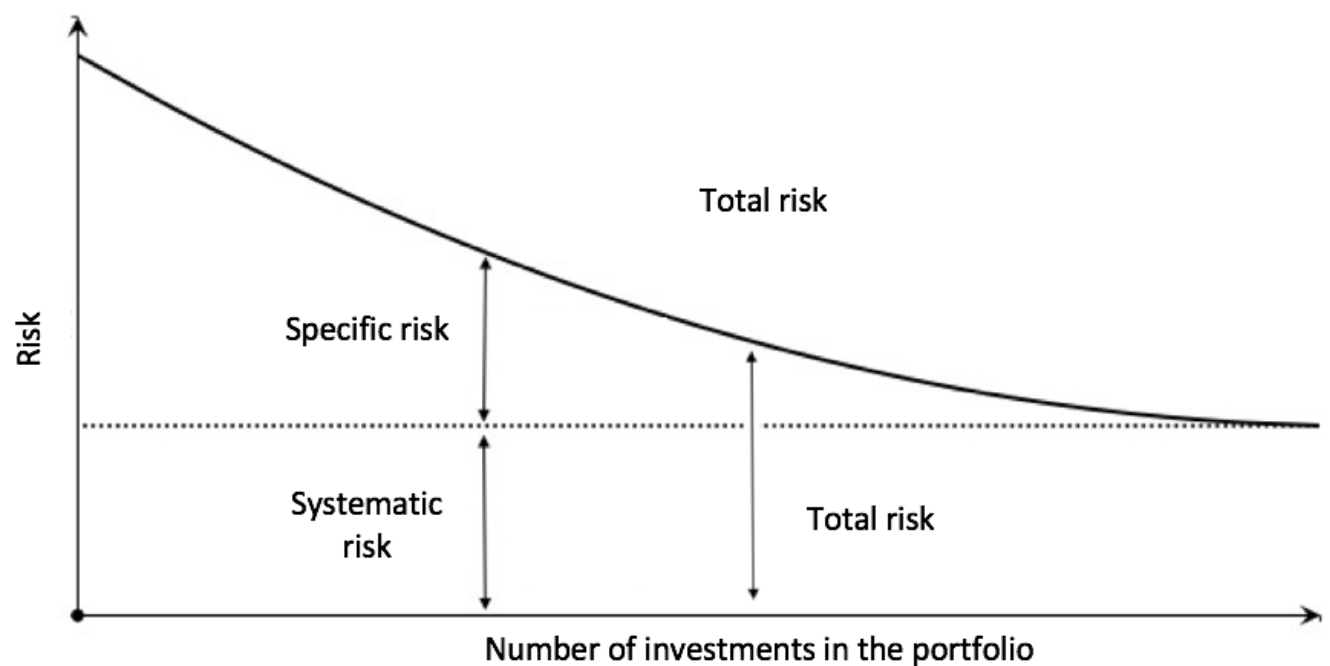

Fig. 1. The impact of diversification on the level of risk (Kryzia 2014)

Rys. 1. Wpływ dywersyfikacji na poziom ryzyka

\section{Types of investment risk}

This section presents and discusses various types of investment risk. It should be noted that this list does not exhaust all possibilities - the list may change each time the risk is assessed for a particular investment. This is due to the specificity and uniqueness of each investment. In addition, the presented set of risk groups refers in particular to energy investments, but it can also be applied to other branches of the economy. A detailed description of the risk groups is shown in Table 1.

TABLE 1. The list of risk groups

TABELA 1. Zestawienie grup ryzyka

\begin{tabular}{|l|l|}
\hline & $\begin{array}{l}\text { This risk can be defined as the threat of a lack of market participation arising from } \\
\text { competition. The size and scope of a single investment usually does not significantly } \\
\text { affect the balance on a mature market, characterized by high competitiveness. In such } \\
\text { markets, the success of the investment should be determined by comparing the quantity } \\
\text { with the price. The price of the balance and, at the same time, the amount of the purcha- } \\
\text { Market risk } \\
\text { sed goods should result from the intersection of demand and supply curves determining } \\
\text { the price and quantity. Under market conditions, this adjustment may lead to the lack of } \\
\text { market interest in the purchase of goods of a given manufacturer, which may result in } \\
\text { a failure of the investment (Liu and Zeng 2017). The discussed risk is accompanied by } \\
\text { other risk groups including, among others: the risk of supply and demand, the risk of } \\
\text { market competition, or price risk. }\end{array}$ \\
\hline
\end{tabular}


TABLE $1 \mathrm{~cd}$.

TABELA 1 cont.

\begin{tabular}{|c|c|}
\hline Price risk & $\begin{array}{l}\text { The price of the products offered in the free market is subject to constant change resul- } \\
\text { ting from the relation between the quantity and the price of the offered products. The } \\
\text { price risk is manifested in two basic aspects, namely: } \\
\text { The risk of changing the price of the product, } \\
\text { The risk of changing prices of semi-finished products or components affecting the } \\
\text { final price of the product. In the energy sector, this group includes: the prices of } \\
\text { emission allowances, the price of energy or fuel, the prices of certificates of the } \\
\text { origin of goods, the cost of labor. } \\
\text { The correct estimation of the economic effectiveness of the project requires certain } \\
\text { assumptions regarding the electricity prices to be made. Due to the price risk, these } \\
\text { assumptions are subject to a certain error, the greater the further they go into the future } \\
\text { (Kryzia 2015). }\end{array}$ \\
\hline Political risk & $\begin{array}{l}\text { The political risk can manifest itself in two basic forms. The first form is related to the } \\
\text { context of possible legal changes. The second is the possibility of the influence of inter- } \\
\text { governmental relations on the normal course of the investment (Marcinek 2010). The } \\
\text { policy affects the direction of development of the economy of a given state or region, } \\
\text { thus affecting each investment decision. The political risk is difficult to diversify, which } \\
\text { makes a quantitative description difficult. A quantitative description of the risk in rela- } \\
\text { tion to the policy of the state has already been given (Liu and Zeng 2017). The basic risk } \\
\text { factors include issues such as tariff policy, industry regulation policy, warranty policy, } \\
\text { and regulations applicable to the entire industry. } \\
\text { The political risk group may include the legal risk subcategory. This is related to the } \\
\text { rules and regulations that negatively affect the course of the investment. These include } \\
\text { (Marcinek 2010): } \\
\text { Overregulation, i.e. too many regulations making it impossible to carry out the } \\
\text { investment efficiently; } \\
\text { Underregulation., i.e. an insufficient legal description of a given aspect; } \\
\text { Dynamic legal developments; when implementing long-term investment, changes } \\
\text { in the law may require a revision of the investment strategy. }\end{array}$ \\
\hline Financial risk & $\begin{array}{l}\text { The primary goal of a private entrepreneur is to optimize revenues. The financial risk } \\
\text { is the risk of that the investment will not be profitable. This situation may be caused by } \\
\text { many factors affecting cash flow disturbances in given periods. }\end{array}$ \\
\hline Operational risk & $\begin{array}{l}\text { This results from the possibility of improper management of the company's resources, } \\
\text { in particular human, technical, or financial resources. The operational risk group also } \\
\text { includes disturbances in the internal structure of the company, as well as the dishonesty } \\
\text { of employees or shareholders (Blim 2008; Bacon 2012). }\end{array}$ \\
\hline Environmental risk & $\begin{array}{l}\text { It is the risk of a negative impact of a given project on the surrounding ecosystem. It } \\
\text { does not always affect economic efficiency, but it can cause additional costs, for exam- } \\
\text { ple social costs or fines (Blanqué et al. 2016). }\end{array}$ \\
\hline $\begin{array}{l}\text { The risk of failure to meet } \\
\text { the construction schedule }\end{array}$ & $\begin{array}{l}\text { This is the possibility of postponing the date of completion of the project. The delayed } \\
\text { start of the operations can cause difficulty with maintaining financial liquidity (Blanqué } \\
\text { et al. 2016; Kaczmarek 2008). }\end{array}$ \\
\hline Technical risk & $\begin{array}{l}\text { This is the possibility of improper operation or the unavailability of a given element of } \\
\text { the infrastructure, in this case the power grid or generating unit. }\end{array}$ \\
\hline
\end{tabular}


TABLE 1 cont.

TABELA $1 \mathrm{~cd}$.

\begin{tabular}{|c|l|}
\hline Credit risk & $\begin{array}{l}\text { Excessive debt can lead to the lack of liquidity of the investment or the entire company; } \\
\text { this is of particular importance in the case of large-budget investments in the energy } \\
\text { infrastructure, which are financed from own and external funds (Ostrowska 2002). This } \\
\text { risk means the possible lack of liquidity due to a wrong credit decision or any other form } \\
\text { of equity funding. A wrong credit decision negatively affects the investment (Kryzia } \\
\text { 2014). }\end{array}$ \\
\hline Technological risk & $\begin{array}{l}\text { This risk should be considered in two ways. The first aspect is the inability to find } \\
\text { innovative solutions and the loss of dedicated funds. The second is the emergence of } \\
\text { new solutions, significantly exceeding the efficiency of those currently available in the } \\
\text { market (Malinowski 2013). }\end{array}$ \\
\hline
\end{tabular}

\section{The identification of risk}

The primary element, indicated by the authors as the most important in the integrated risk management process, is the correct identification. Numerous methods have been developed in order to correctly diagnose as many risk groups as possible. They include:

1. Checklists - the method involves answering a series of questions prepared by a group of experts. Of course, the success of this method is dependent on the accuracy and completeness of the questions asked. The answer to well-chosen questions should bring a comprehensive picture of the risk in the investment (Marcinek 2010).

2. The Delphi method - its basic version is based on experts' opinions. In this case, the problem is presented to a panel of experts from various fields, who are then asked to prepare an opinion or response. To avoid the duplication of errors, working in isolation from other team members is suggested. After collecting and systematizing the results, they are presented to the group; then, another expert opinion is requested (Marcinek 2010).

3. The nominal group technique - this method is similar to the Delphi Method. The difference is that experts can work in groups. It consists of the basic elements, which include: the selection of experts, discussion of the problem or scope of investment, preparation of opinions, and reconsideration of the discussed issue by everyone involved in the process. As in the case of the Delphi Method, this process can be repeated many times during the investment. These methods are particularly useful when identifying potential risk groups (Marcinek 2010).

4. The brainstorming method and public debate - the very concept of brainstorming is commonly understood. This is most often a joint discussion on a given issue, aimed at the best possible solution to a given problem. By adopting such assumptions, a special case of "brainstorming" can be a public debate. This may prove particularly useful due 
to the involvement of both opponents and supporters of a given investment (Marcinek 2010).

5. Holistic methods - a group of methods supporting the analysis of a given topic. These are focused on determining the possible relations between individual elements. Holistic methods include, among others:

$\checkmark$ The large drawing analysis;

\ The map of the system;

$\checkmark$ The method of formal model.

The "Large drawing analysis" analyzes a graphic image of the elements of a given system along with their interrelations. In addition to relations resulting from legal or technical dependencies, a number of interpersonal relations or possible conflicts can also be determined. The relationships presented in the analysis may include, among others, supremacy, subordination, dependence, independence, communication, or chronology.

The map of the system presents all possible relationships between elements of the investment in a chart form. This enables you to present the relations between elements in the process. The visualization of the method of the formal model, showing the formal relations between the elements of the investment, takes on a similar form.

\section{The risk countermeasures}

Investors can reduce risk using a range of instruments, including (Blanqué et al. 2016; Ostrowska 2002; Zachorowska 2006):

४ Avoiding the risk, by discontinuing investments in high risk projects;

$\uparrow$ Risk reduction:

Diversification - reducing the risk by spreading it into many investments or products,

- Risk compensation, e.g. hedging;

$\checkmark$ Risk transfer to the insurer or subcontractors;

$\checkmark$ Financing - covering the risk with equity.

In fact, it is possible to use all these elements. The risk reduction scheme is shown in Figure 2. 


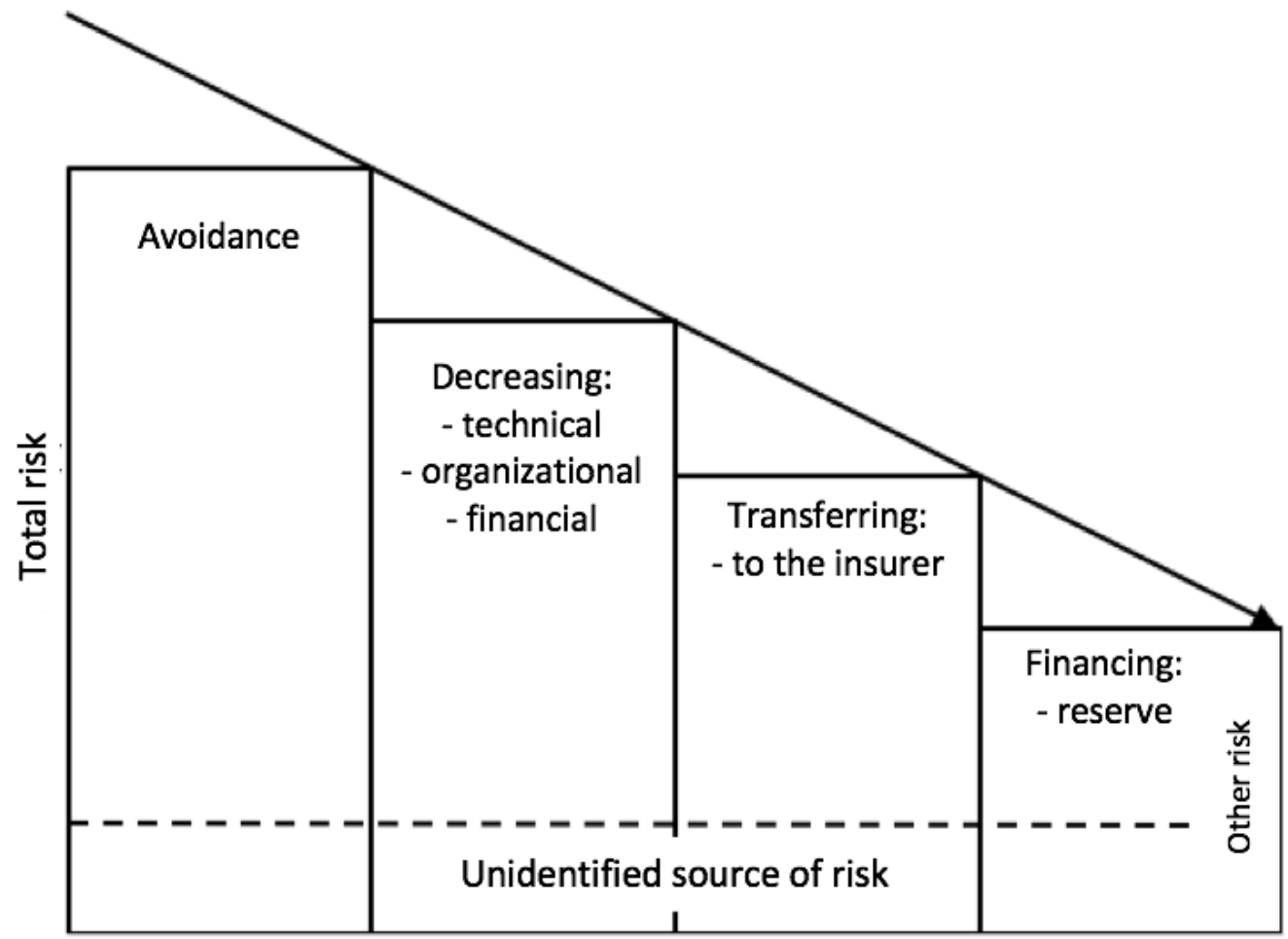

Fig. 2. Risk management (Zachorowska 2006)

Rys. 2. Zarządzanie ryzykiem

\section{The quantification of risk}

The quantification of risk is the quantitative description aimed at quantifying the level of risk. However, as mentioned in the section on risk categories, many of them are not easy to quantify due to their unpredictable nature. In addition, the dynamics of changes over time and the multitude of factors determining the investment risk make it difficult to determine the likelihood of events (Ostrowska 2002). The basic groups of quantitative risk description methods include, among others:

$\downarrow$ Financial methods,

$\checkmark$ Sensitivity methods,

$\checkmark$ Statistical methods,

$\checkmark$ Probabilistic methods,

$\checkmark$ Simulation methods, 
$\downarrow$ Network methods,

$\downarrow$ Decision-making tree methods,

$\downarrow$ Expert methods.

The simplest methods from the group of financial methods are NPV and IRR indicators. Although these methods are recognized as methods for determining the level of risk, they can be used for other calculations, as well as provide information about the possible economic effectiveness of the project (Michalak 2013). Combined with the sensitivity analysis, they may describe the financial stability of the investment.

Financial methods also take into account the risk in the discount rate, which takes the following form (Marcinek 2010):

$$
i_{c}=\left(1+i_{f}\right)\left(1+i_{i}\right)\left(1+i_{r}\right)-1
$$

Where:

$i_{\mathrm{c}}$ - the total rate including standard rate, inflation, and risk,

$i_{(f)}-$ standard risk-free rate,

$i_{i}-$ inflation,

$i_{r}-$ the risk premium.

Simulation methods make up one of the groups of quantitative risk assessment methods. The most popular of these is the Monte Carlo method, based on repeated drawing of certain values affecting the model built on the basis of earlier observations. Its principal advantage is the possibility of taking the volatility of many factors ultimately determining the result into account (Krawczyk 2013; Marcinek 2010).

Another one is the Value at Risk method. This is the maximum amount of money that may be lost on a portfolio with a given level of confidence. This method is based on probability analysis using statistical distributions (Krawczyk 2013; Sadeghi and Shavvalpour 2006). The $\mathrm{VaR}$ method is one of the most common methods to assess the total risk. Its main advantage is the simplicity of the interpretation of the results; it can also be used for a numerical description of the largest possible changes in the given investment parameters, for example fuel prices (Andriosopoulos and Nomikos 2013; Sadeghi and Shavvalpour 2006). There are a number of possible ways of calculating the VaR, including (Andriosopoulos and Nomikos 2013; Sadeghi and Shavvalpour 2006; Aven et al. 2012):

1. Historical method;

2. Monte Carlo method;

3. Variance method.

VaR can be described using the following relationship (Andriosopoulos and Nomikos 2013):

$$
P\left(r_{t+1} \leq \operatorname{VaR}_{t+1}^{\alpha} \mid \Omega_{t}\right)=\alpha
$$


Where:

$r_{t+1}-$ return over the time horizon,

$\alpha \quad-$ the confidence level,

$\Omega_{t} \quad-$ data at time $t$.

The VaR method has been repeatedly modified and adapted to the specificities of the investment (Fertis et al. 2012).

\section{Risk analysis on the example of an agricultural biogas plant}

For the purposes of the analysis, a number of technical and economic assumptions for the exemplary biogas plant was adopted, including:

$\checkmark$ Mesophyll digestion,

Single-stage fermentation,

$\checkmark$ High performance cogeneration,

$\checkmark$ The installed electrical capacity $-2 \mathrm{MW}$,

$\checkmark$ The expected life -20 years,

$\checkmark$ The investment in the investor's premises,

\ Substrates from animal husbandry carried out in the investor's farm,

$\checkmark$ Corn silage and other vegetable waste available in the market at the price of PLN 80 /ton,

४ The annual biogas plant operation time $-8000 \mathrm{~h}$,

$\checkmark$ Thermal efficiency - about $45 \%$,

$\checkmark$ Electrical efficiency - about $40 \%$,

- The use of digestate pulp on own fields,

$\checkmark$ The area adapted to the implementation of this type of investment,

\ The unit cost is PLN 13 million/MW,

$\checkmark$ Additional one-time costs of PLN 410000.

The values characterizing the investment were calculated on the basis of the above assumptions. The gas production is around 7,300,000 m 3 year $\left(\approx 4383000 \mathrm{~m}^{3}\right.$ methane per year). The electric power is $2 \mathrm{MW}$ and the thermal power is $2.25 \mathrm{MW}$, of which $9 \%$ and $21 \%$ are consumed for own needs of the system, respectively.

The exemplary application of selected elements of the investment risk management methodology is presented below. The procedures recommended during the analysis of the actual uncertainty, according to which the first element is the identification of risk, were maintained. Figure 3 presents a visualization of the "Large drawing analysis" method, used to diagnose groups of threats to investments and links between individual elements (Curkowski 2011).

Next, it is possible to describe the selected risk categories in numerical form. When it comes to the quantification of risk, the most common group is made up of elements related to the eco- 


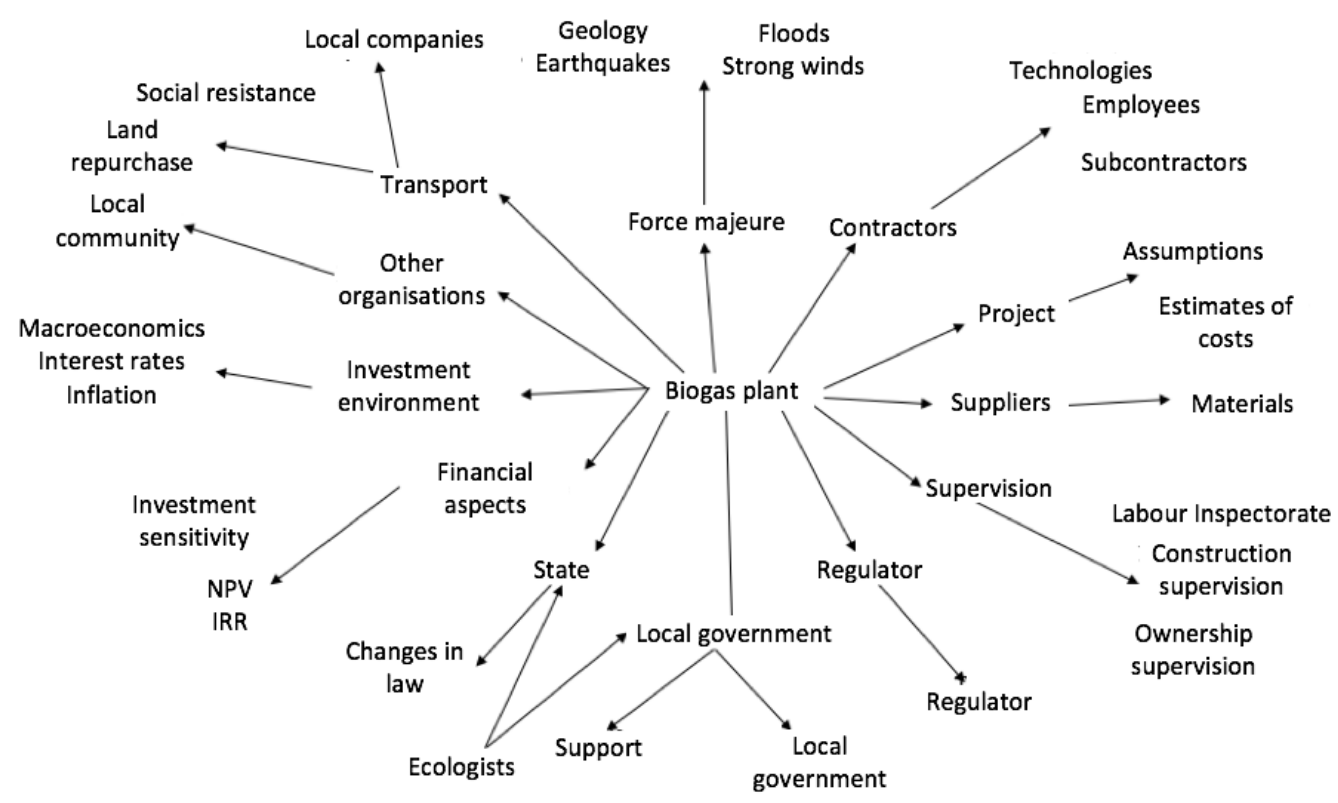

Fig. 3. The simplified "Large drawing analysis" for biogas plant

Rys. 3. Przykładowa uproszczona „Analiza dużego rysunku” dla biogazowni

nomic efficiency of the project. The basic tool is the NPV indicator, which can be used in subsequent calculations and methods for determining the level of risk.

Another method commonly used in determining the risk is the Monte Carlo simulation. In the first phase of the study, financial flows should be assumed in each of the periods considered; on this basis, the flows in each of these periods can be simulated. The results of the sample simulation are shown in Figure 4.

Then 1000 samples of random NPV values were simulated on the basis of random financial flows. The results are presented in the form of a histogram in Figure 5.

The simulation allows determining the NPV probability distribution for a given type of project and the probability of economic inefficiency. The detailed results are presented in Table 2.

Another indicator used in the risk quantification process is VaR, which is the measure of the largest possible loss from the investment (Krawczyk 2013). To perform the calculations, it was necessary to assume the confidence level, which in this case was 0.95 . The study used data from the Monte Carlo simulations shown above. The results are summarized in Table 3.

On the basis of the above analyzes, the risk profile of investments of a similar type can be determined. The enormous complexity of the construction process and the preceding preparation process, presented in Figure 3 is particularly noteworthy. Statistical parameters of the Monte Carlo simulations and VaR indicate that a negative financial result of the project is unlikely. Thus, the investment is low risk and the economic efficiency that could satisfy the investor is likely to be achieved. 


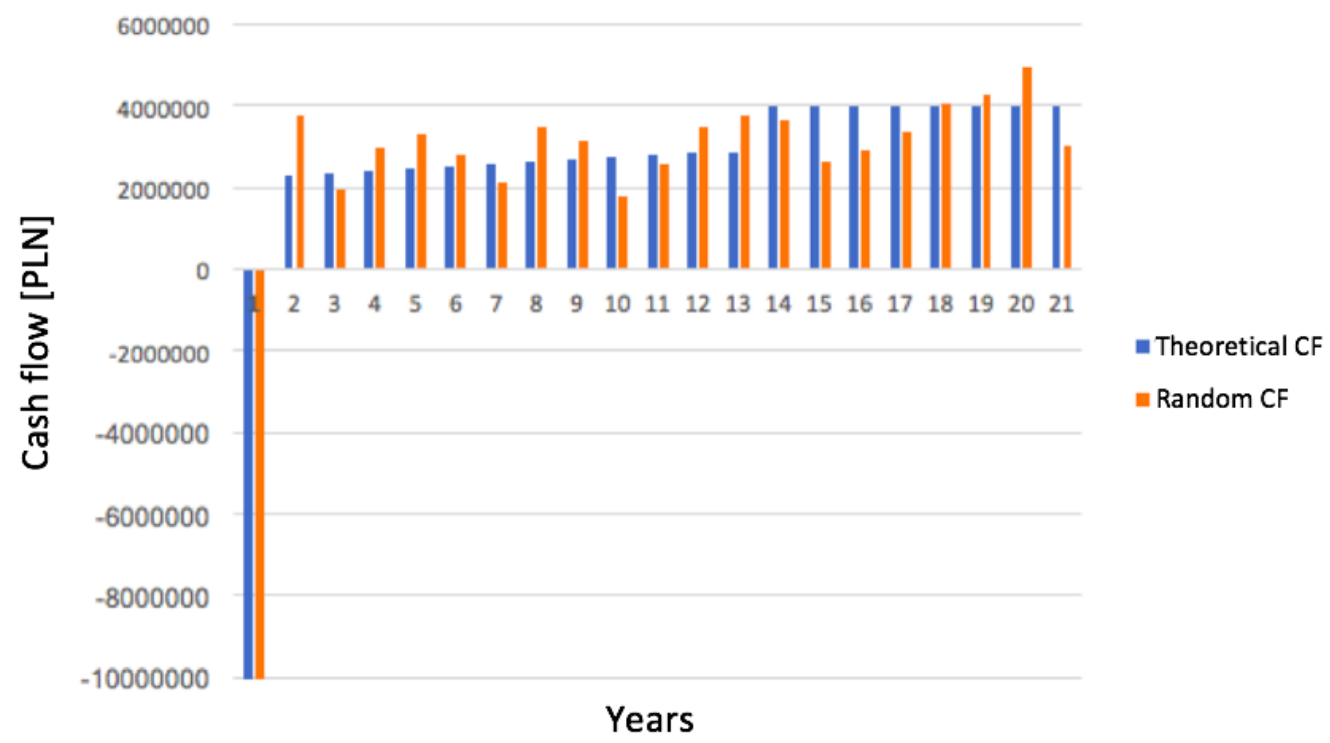

Fig. 4. The theoretical and exemplary, based on the Monte Carlo method, cash flow chart

Rys. 4. Wykres teoretycznego oraz przykładowego, określonego metodą Monte Carlo, poziomu przepływów pieniężnych

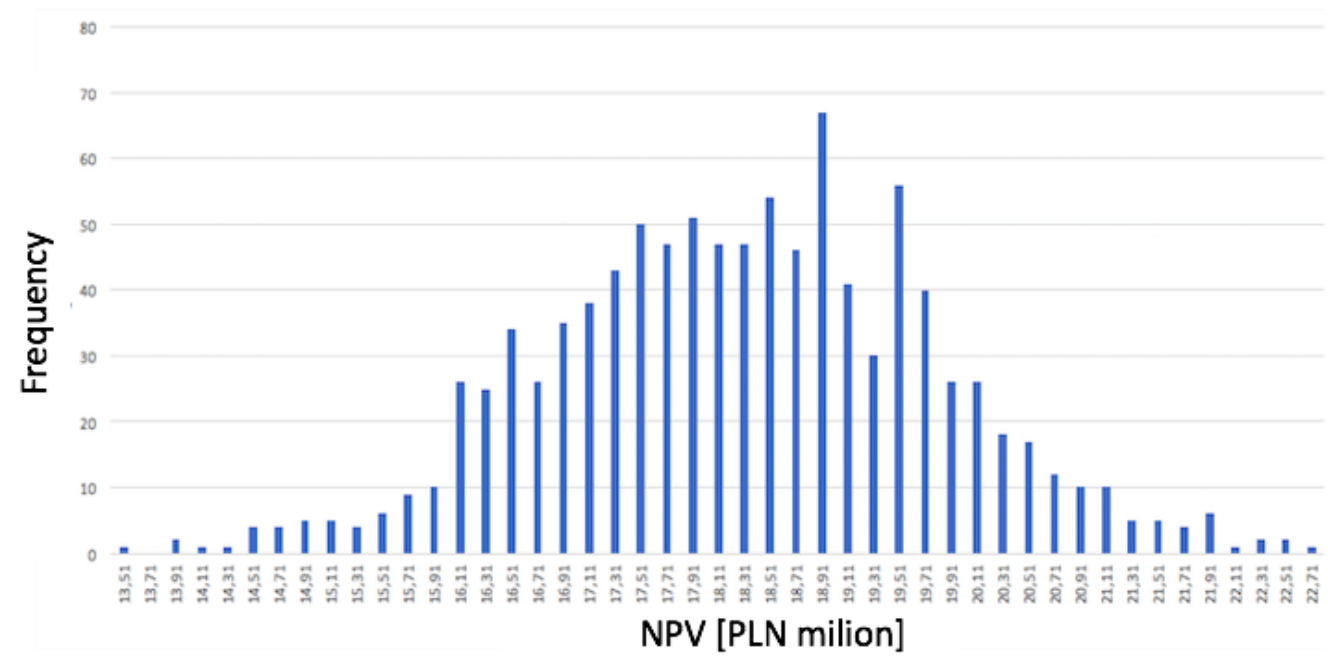

Fig. 5. The histogram of the frequency of specific ranges of NPV values

Rys. 5. Histogram częstości występowania określonych wartości NPV 
TABLE 2. Monte Carlo simulation results [PLN]

TABELA 2. Wyniki symulacji Monte Carlo [zł]

\begin{tabular}{|l|c|}
\hline The average NPV & $18,193,050.6$ \\
\hline The standard deviation of NPV & $1,491,947.6$ \\
\hline The standard error of average NPV & $47,179.5$ \\
\hline NPV median & $18,217,334.4$ \\
\hline Skewness & -0.020 \\
\hline Range & $9,201,124.1$ \\
\hline Minimum & $13,488,995.3$ \\
\hline Maximum & $22,690,119.4$ \\
\hline
\end{tabular}

TABLE 3. Results of VaR calculations

TABELA 3. Wyniki obliczeń VaR

\begin{tabular}{|l|c|}
\hline Average NPV (PLN) & $18,193,050.6$ \\
\hline The standard deviation of NPV (PLN) & $1,491,947.6$ \\
\hline The confidence level & 0.95 \\
\hline VaR (PLN) & $2,454,035.4$ \\
\hline
\end{tabular}

\section{Conclusions}

The calculations presented in this study indicate the security of investment in the analyzed biogas plant while the description of the detection methods and potential risk groups presented in part one may serve as a framework for analyzing other investments. The work presents the individual elements of the investment risk management in the energy sector and indicates the ones that can be problematic in actual market analyses. A huge range of analytical capabilities that support making investment decisions in risk conditions is currently available. The paper presents examples of their possible application, focusing on the quantification of risk, assuming that some risk elements are difficult to quantify. The original risk analysis is the starting point for actions to reduce it, for example through insurance or transfer to other entities. Particular attention should be paid to risk issues in the case of large investment, a typical examples of which are energy infrastructure projects. 


\section{References}

ANDRIOSOPOULOS, K. and NOMIKOS, N. 2013. Risk management in the energy markets and Value-at-Risk modelling: a hybrid approach. The European Journal of Finance, pp. 1-27.

Aven et al. 2012 - Aven, T., ZIO, E., BARALDI, P. and FlAGE, R. 2012. Uncertainty in Risk Assessment: The Representation and Treatment of Uncertainties by Probabilistic and Non-Probabilistic Methods. Chichester: John Wiley \& Sons.

BACON, C.R. 2012. Practical Risk-Adjusted Performance Measurement. Somerset: John Wiley \& Sons.

BAJOR, M. 2016. Risks associated with investing in renewable energy sources in Poland (Ryzyko towarzyszące inwestowaniu w odnawialne źródła energii w Polsce). Research Reviews of Czestochowa University of Technology - Management no. 24, vol. 2, pp. 272-280 (in Polish).

BARAN et al. 2016 - BARAN, Ł., BIELECKI, S. and SKOCZKOWSKI, T. 2016. Renewable energy sources problems and perspectives of development in Poland (Odnawialne źródta energii - problemy i perspektywy rozwoju w Polsce). Przeglad Elektrotechniczny no. 3, pp. 190-195 (in Polish).

Blanqué et al. 2016 - Blanqué, P., De Jong, M. and Ithurbide, P. 2016. Appraising investment risk. Journal of Asset Management vol. 17, pp. 215-217.

BLIM, M. 2008. Operational risk management (Zarzadzanie ryzykiem operacyjnym). C.H. Beck, Warsaw (in Polish).

CONCHÚIR, D.Ó. 2011. Overview of the PMBOK® Guide. Berlin: Springer Berlin Heidelberg.

CURKOWSKI, A. 2011. A guide for investors interested in the construction of agricultural biogas plants (Przewodnik dla inwestorów zainteresowanych budową biogazowni rolniczych). Institute for Renewable Energy, Warsaw (in Polish).

FERTIS et al. 2012 - FERTIS, A., BAES, M. and LÜTHI, H.-J. 2012. Robust risk management. European Journal of Operational Research vol. 222, pp. 663-672.

HINDE, D. 2012. PRINCE2 study guide. Chihester: John Wiley \& Sons, Ltd.

KACZMAREK, T.T. 2008. Risks and Risk Management. Interdisciplinary Approach (Ryzyko i zarzadzanie ryzykiem: ujęcie interdyscyplinarne). Warszawa: Difin (in Polish).

Косот, Н. 2013. Electricity generation costs and the risk of investment (Koszty wytwarzania energii elektrycznej a ryzyko inwestycyjne). Rynek Energii no. 2, pp. 29-34 (in Polish).

KRAWCZYK, T. 2013. Investment risk modeling: practical applications using the Excel spreadsheet and the Gretl software (Modelowanie ryzyka inwestycyjnego: zastosowania praktyczne $z$ wykorzystaniem arkusza kalkulacyjnego Excel i programu Gretl). Warsaw: CeDeWu (in Polish).

KRYZIA, D. 2014. Method of selection electricity generation technology-based on risk analysis and value of energy company (Metoda doboru technologii wytwarzania energii elektrycznej w oparciu o analizę ryzyka i wartości przedsiębiorstwa energetycznego). Doctoral dissertation, Kraków (in Polish).

KRYZIA, D. 2015. Selection of the electricity generation technologyin the risk conditions (Wybór technologii wytwarzania energii elektrycznej $w$ warunkach ryzyka). Kraków: The Publishing House of the Mineral and Energy Economy Research Institute of the Polish Academy of Sciences (in Polish).

LIU, X. and ZENG, M. 2017. Renewable energy investment risk evaluation model based on system dynamics. Renewable and Sustainable Energy Reviews vol. 73, pp. 782-788.

MALINOWSKI, A. 2013. Risk in the assessment of economic projects - models and methods of analysis (Ryzyko w ocenie projektów gospodarczych - modele i metody analizy). Warsaw: Difin (in Polish).

MARCINEK, K. 2010. Risk in the financial assessment of investment projects: selected issues (Ryzyko w ocenie finansowej projektów inwestycyjnych: wybrane zagadnienia). Katowice: Publishing House of the University of Economics in Katowice (in Polish). 
MAZUR et al. 2015 - MAZUR, K., MrÓZ, W. and WNUK, A. 2015. Assessment of investment risk from the environmental point of view (Ocena ryzyka inwestycyjnego w aspekcie środowiskowym). Paliwa i Energetyka no. 1, pp. 60-62 (in Polish).

MichaLAK, J. 2013. Selected methods aiding investment decisions in power engineering (Wybrane metody wspomagające podejmowanie decyzji inwestycyjnych $w$ energetyce). Polityka Energetyczna - Energy Policy Journal vol. 16, iss. 4, pp. 77-86 (in Polish).

MiCHALAK, J. 2014. Risk in renewable power engineering investment projects (Ryzyko w projektach inwestycyjnych energetyki odnawialnej). Poznan University Of Technology Academic Journals no. 79, pp. 105-111 (in Polish).

OSTROWSKA, E. 2002. The risk of investment projects (Ryzyko projektów inwestycyjnych). Warsaw: PWE (in Polish).

Ryzyko 2018. Dictionary of Polish Language (Stownik Jęzka Polskiego). [Online] http://sjp.pwn.pl/szukaj/Ryzyko.html [Accessed: 2018-09-10].

SAdEGHI, M. and ShaVVALPOUR, S. 2006. Energy risk management and value at risk modeling. Energy Policy vol. 34, pp. 3367-3373.

ZACHOROWSKA, A. 2006. Investment risk of enterprises (Ryzyko dziatalności inwestycyjnej przedsiębiorstw). Warsaw: PWE (in Polish).

\section{Ryzyko inwestycyjne w energetyce na przykładzie biogazowni}

\section{Streszczenie}

Celem artykułu jest przedstawienie zagadnienia ryzyka oraz powiązanych z nim metod zarządzania, ze szczególnym uwzględnieniem warunków inwestycji w infrastrukturę energetyczną. Praca składa się z dwóch głównych części - w pierwszej z nich dokonano analizy teoretycznej zagadnienia, natomiast $\mathrm{w}$ drugiej przedstawiono zastosowanie metod analizy na przykładzie realizacji inwestycji w biogazownię rolniczą.

W artykule przedstawiono podstawowe definicje związane z zagadnieniem ryzyka inwestycyjnego i zarządzania nim; w szczególności dokonano rozróżnienia pojęcia ryzyka i niepewności. Ponadto analizie poddano główne grupy ryzyka, specyficzne dla sektora energetycznego. Następnie przedstawiono podstawową systematykę oraz możliwe kategorie podziałów grup ryzyka oraz określono wpływ dywersyfikacji inwestycji w portfelu na ogólny poziom ryzyka. Omówiono źródła niepewności, w szczególności kierując się kategoriami występującymi w przypadku inwestycji energetycznych. W kolejnej części pracy przedstawiono metody mitygacji ryzyka, będące elementem zintegrowanego procesu zarządzania ryzykiem oraz opisano podstawowe metody wspomagające ilościowe określenie poziomu ryzyka oraz jego skutków w tym metodę Monte Carlo (MC), Value at risk (VaR) oraz inne. W ostatniej części pracy przedstawiono możliwe zastosowanie metod przedstawionych w części teoretycznej. Przedmiotem przykładowej analizy była inwestycja w biogazownię rolniczą, ze względu na przewidywalny charakter jej pracy, przy jednocze- 
śnie złożonym i długim okresie procesu inwestycyjnego. Przedstawiono przykład „Analizy dużego rysunku", a następnie przeprowadzono symulację Monte Carlo oraz określono wartość VaR. Przeprowadzone badania pozwalają na określenie poziomu ryzyka wynikającego z odchylenia wartości przepływów finansowych w poszczególnych okresach od wartości założonych oraz pomagają w określeniu skutków takich odstępstw. Przeprowadzona analiza wskazała na niskie ryzyko przedmiotowej inwestycji oraz sugeruje łatwość przeprowadzenia podobnych obliczeń dla innych inwestycji energetycznych.

SŁowA KLUCZOWE: Ryzyko inwestycyjne, zarządzanie ryzykiem, niepewność, Monte Carlo, Value at risk, biogazownia 